\title{
GENETIC BACKGROUND AND EFFECTS OF EXCESSIVE IRON STORAGE IN DIFFERENT MAMMALIAN SPECIES
}

Department of Genetics and Animal Breeding, Warsaw University of Life Sciences - SGGW, Poland

\begin{abstract}
Hemochromatosis is a metabolic disease associated with excessive iron storage in the body. At present, we distinguish between 5 types of this disease that differ in their genetic background and inheritance, as well as the frequency of occurrence. Due to the possibility of fatalities, excessive iron storage is a more serious disorder than its deficiency. In this disease, iron is accumulated in the body in the form of hemosiderin, a protein complex that store iron in cells. The occurrence of this disease was observed not only in humans, but also in other animal species such as the red deer, black rhinoceros, house mouse or domestic cattle. This article is a review of the current state of knowledge about hemochromatosis in humans, normal iron metabolism, and about the occurrence of this disease in the red deer and its impact on the biology and population of this species.
\end{abstract}

Key words: hemochromatosis, red deer, iron metabolism.

\section{INTRODUCTION}

Iron is one of the most important trace elements necessary for the proper functioning of living organisms. Hemochromatosis is a metabolic disease associated with excessive accumulation of this element in the body. Due to the possibility of fatalities, excessive iron storage is a more serious disorder than its deficiency. In hemochromatosis, iron is accumulated in the body in the form of hemosiderin, a protein complex that store iron in cells. There are two forms of hemochromatosis, i.e. a primary form, otherwise known as inherited or hereditary, which is characterized by abnormal functioning of the system of iron removal from the body and a secondary form in which erythrocytes and liver cells release too much iron ions, which then accumulate in the tissues of the body (Korzeniowska et al. 2012). Iron is deposited in many organs, including lungs, kidneys, heart, pancreas, endocrine glands, but mainly in bone marrow and liver.

\section{NORMAL IRON METABOLISM}

In healthy individuals with undisturbed iron deposition its metabolism begins at the stage of its transport and absorption into the blood. Absorption takes place primarily in the duodenum and is strictly controlled by the hormonal balance of the body. The apical

Corresponding author: Paweł Kołomyja, Department of Genetics and Animal Breeding, Warsaw University of Life Sciences - SGGW, Jana Ciszewskiego 8, 02-786 Warszawa, Poland, e-mail: pawelkolomyja@gmail.com 
endocytes located in the upper part of the intestinal villi are responsible for iron absorption and are characterized by the presence of two sets of proteins: transporting and regulating the oxidation state of iron ions. The absorption process itself is a complex one, for it requires a double change in the oxidation state of ions and their transporting by two opposite enterocyte membranes: apical, facing the duodenum and basolateral, contacting the blood vessels of the body. On the apical membrane of enterocyte there is duodenal cytochrome b (DCYTB), which function is reduction of $\mathrm{Fe}^{3+}$ ions to the $\mathrm{Fe}^{2+}$ form. In this form iron can be transported inside the enterocyte by the divalent metal transporter 1 - DMT1 protein (Zabielski 2005; Lipiński et al. 2014). After penetration into enterocytes iron ions bind with apoferrin at its active site, and this causes its transformation into ferritin, which plays important role in the process of iron absorption (Chmielnicka 2012). This protein stores iron ions and also acts as a buffer protein i.e. regulates the level of iron ions taken from the duodenum, penetrating into the so-called labile iron pool (LIP) in the cytoplasm (Zabielski 2005). Iron is then transported to blood vessels using ferroportin, which interacts with the basal-lateral, copper-dependent ferrooxidase, known as hephaestin, which oxidizes iron ions to $\mathrm{Fe}^{3+}$ form, in which they can form stable complexes with transferrin (Lipiński et al. 2014).

Regulation of ferritin expression takes place at the level of translation, with participation of iron-sulphur regulatory protein - IRP1. Homeostasis between the iron level in LIP and the level of ferritin expression is regulated by the LIP-IRP1-Ft-LIP feedback. Additionally, a protein called hepcidin (HAMP) synthesized in hepatocytes and released into the bloodstream is involved in inhibition of iron absorption from the gastrointestinal tract (Zabielski 2005). Although ferritin is found in all cells of the body, iron is used primarily from the ferritin of cells belonging to the reticuloendothelial system of the liver, spleen, bone marrow, as well as iron accumulated in ferritin from hepatocytes. Iron that separates from ferritin via oxidationreduction goes to plasma and oxidizes to $\mathrm{Fe}^{3+}$ ions that can bind with transferrin. $\mathrm{A}$ single molecule of this glycoprotein is able to bind two $\mathrm{Fe}^{3+}$ ions; in a healthy subject only $1 / 3$ of the circulating blood transferrin is saturated with iron. It distributes iron to bone marrow, liver or muscle and also to other tissues. The transferrin-iron complex is bound by erythroblasts containing transferrin-specific receptors on their surface. In the bone marrow, after binding with the receptor, endocytosis of the whole compound to the lysosomes occurs, then the detached iron is bound to cell mitochondria and apotransferrin is released outside the cell into circulation.

There is a reduction in the oxidation state of iron and in the form of $\mathrm{Fe}^{2+}$ it binds to protoporphyrin IX via ferrochelatase in the inner chambers of the mitochondria, leading to the formation of haem. Haem binds with globulin through coordination bonds of the iron and forms haemoglobin. In erythrocytes, iron ions can bind not only to ferritin, but also to hemosiderin, which is a product of ferritin degradation. The iron-hemosiderin complex is characterized by a slower release of iron than when it is combined with ferritin; therefore iron stored in this way is called the inactive pool, which is deposited in the liver, spleen and bone marrow. Iron from broken erythrocytes gets into erythroblasts, and a number of iron-filled enterocytes are exfoliated into the intestinal lumen from where iron is expelled from the body (Chmielnicka 2012). 


\section{HEMOCHROMATOSIS IN HUMANS}

This disease was first described in man in 1865 when the symptom triad characteristic for its occurrence was indicated. The name of the disease itself was used for the first time in 1889 and in 1935 it was suggested to be inherited (Pietrangelo et al. 1995). However, it was not until 1977 that the mode of its inheritance was determined (Simon et al. 1997). Congenital hemochromatosis is considered the most common metabolic disorder and its occurrence is estimated at 3-8 cases per 1.000 individuals of the Caucasian population in which it occurs most often (Edwards et al. 1988; Phatak et al. 1998; Sikorska et al. 2006). The main causes of the secondary pathological deposition of iron, i.e. secondary hemochromatosis, are anemia and excessive supply of this element (Derc et al. 2001; Raszeja-Wyszomirska et al. 2008; Korzeniewska et al. 2012; Kulej et al. 2012). Originally, the genetic background of human congenital hemochromatosis was considered a mutation of the HFE gene encoding human hemochromatosis protein. In humans the gene is located on chromosome 6 (6q22.2), and the abbreviation HFE is derived from the words High Iron Fe. The protein encoded by the HFE gene is a membrane protein similar to MHC class I proteins and binding to $\beta-2$ microglobulin $(\beta 2 \mathrm{M})$. This protein is thought to regulate the uptake of circulating iron by regulating the interaction of the transferrin receptor with transferrin (NCBI, 2018). The highest expression of this gene has been observed so far in tissues such as: brain (mainly nerve cells), appendix (mainly glandular cells), heart (myocytes), rectum (mainly glandular cells) and fallopian tube (glandular cells), while its expression was not detected in bone marrow and smooth muscles.

Other tissues and organs are characterized by medium or low levels of expression of the HFE gene (The Human Protein Atlas 2018). The protein is located primarily in the membrane surrounding cell nucleus and mitochondria (The Human Protein Atlas 2018).

The HFE protein is made up of 343 amino acids, which consists of several components: the signal peptide, which is the initial part of the protein, the extracellular region of the transferrin receptor binding ( $\alpha 1$ and $\alpha 2$ ), the immunoglobulin-like part ( $\alpha 3$ ), the transmembrane region anchoring the protein in the membrane and a short cytoplasmic tail (Feder et al. 1996; The Human Protein Atlas 2018).

Hereditary hemochromatosis (iron storage disorder - $\mathrm{HHC}$ ) is an autosomal recessive disorder, caused by the p.C282Y or p.H63D mutation. In addition, at least 42 mutations in the introns and exons of the HFE gene have been found in hemochromatosis patients or members of their families (Merryweather-Clarke et al. 1997; Merryweather-Clarke et al. 2000; $\mathrm{NIH}$ 2014). Mice with the knockout HFE (Hfe - / -) gene both in exon 1 and 2 and 3, as well as mice with the $\mathrm{C} 282 \mathrm{Y}$ mutation were characterized by the same symptoms as those observed in people with hemochromatosis (Zhou et al. 1998; Bahram et al. 1999; Levy et al. 1999).

Previous studies have identified several types of congenital hemochromatosis with diverse genetic background (Table 1) - Sikorska et al. (2006). At present, only different types of hemochormatosis have been isolated in humans and their genetic background has been recognized. This information is a guide to selecting candidate genes associated with this disease in other mammalian species. 
Table 1. Description of individual types of congenital hemochromatosis in humans

\begin{tabular}{lcclc}
\hline $\begin{array}{c}\text { Hemochromatosis } \\
\text { type }\end{array}$ & Mutant gene & Gene location & Inheritance mode & $\begin{array}{c}\text { Mutation } \\
\text { frequency }\end{array}$ \\
\hline 1 & HFE & $6 \mathrm{p} 22$ & autosomal recessive & common \\
\hline 2A (juvenile) & HJV & $1 \mathrm{q} 21$ & autosomal recessive & rare \\
\hline 2B (juvenile) & HAMP & $19 \mathrm{q} 13$ & autosomal recessive & extremely rare \\
\hline 3 & TFR2 & $7 \mathrm{q} 22$ & autosomal recessive & rare \\
\hline 4 (ferroportin disease) & SLC40A1 & $2 \mathrm{q} 32$ & autosomal dominant & rare \\
\hline
\end{tabular}

Source: Sikorska et al. (2006), modified.

It is assumed that the most important factor regulating iron metabolism in human body is the hepcidin (a peptide synthesized in the liver) and ferroportin (a specific receptor that is responsible for the release of iron from cells) system (Ganz 2003; Robson 2004). All known types of congenital hemochromatosis are caused by dysfunctions in this system. Type 1 disease, associated with the mutation of the HFE gene and type $2 \mathrm{~A}$, associated with the mutation of the HJV gene encoding hemojuvelin, involved in the regulation of hepcidin expression, are characterized by inadequate low expression of the latter (Lanzara et al. 2004). Type 2B is characterized by disorders of hepcidin peptide synthesis due to the mutation of the HAMP gene encoding it (Roetto et al. 2003). In type 3, the disorder of the mechanism regulating iron metabolism is based on disturbances in the hepcidin synthesis by inactivating its modulator - TfR2 transferrin receptor (Nemeth et al. 2005). Type 4 hemochromatosis is associated with the mutation of the ferroportin gene, i.e. iron transporting protein, which is undergoing hepcidin-inhibiting effects (Knutson et al. 2005). Some of the mutations in the SLC4OA1 gene lead to inactivation of the iron ions transporter, while others suppress sensitivity of ferroportin to the inhibitory effect of hepcidin (Drakesmith et al. 2005).

\section{CONSEQUENCES OF EXCESSIVE IRON ACCUMULATION}

An excessive accumulation of iron is a pathological condition that is even more dangerous than a deficiency of this element, since it can eventually lead to the death of the individual. However, the basic effects of excessive accumulation of iron in body tissues include excessive production of reactive oxygen radicals, due to the high oxidative/reductive potential of iron. Damage caused by hemochromatosis will primarily concern the liver, which is the main storage place of iron in cases of elevated levels of this element in the blood. Accumulation of iron in hepatocytes, exceeding the capacity of these cells to safely store this element, contributes to an increase in the level of free radicals, while limiting the ability of hepatocytes to utilize them. As a result of oxidative stress developing in hepatocytes, damage to cell membranes, development of degenerative changes and, consequently, cell death caused by progressive mechanism of necrosis or apoptosis occur (Pietrangelo et al. 1995; Videla et al. 2003; Sikorska 2014). Activation of these processes leads to the activation of hepatic sinus macrophages and then to the release of proinflammatory cytokines, such as TNFa, IL-1, IL-10 or IFN- $\gamma$, growth factors - TGF $\beta 1$ and recruitment of 
lymphocytic cells that form inflammatory infiltrates (Bacon and Britton 1990). As a consequence of inflammatory reaction, stellate cells are activated, together with intense synthesis of extracellular matrix molecules, which gives rise to progressive fibrosis and pathological remodelling of the organ structure (Reeves and Friedman 2002). The risk of progression of liver fibrosis and the development of cirrhosis increases with the duration of exposure to elevated iron concentrations (Hübscher 2003). In the terminal stage of hemochromatosis, symptoms of liver failure appear. In addition, excessive iron levels are significantly correlated with an increased risk of hepatocellular carcinoma (HCC) - Ko et al. (2007). Excessive iron accumulation also affects other organs, not only the liver. It leads to destruction of the glandular structure of the pancreas, resulting in disorders of insulin secretion and development of diabetes. In all types of untreated hemochromatosis, and especially fast in juvenile hemochromatosis, cardiovascular system symptoms develop, eventually leading to cardiomyopathy. Endocrine glands and joint damage can also occur (Sikorska 2014).

Previous studies have shown relationship between the occurrence of hemochromatosis and dysfunctions of organs other than the liver. Some of the earliest literature reports describe the occurrence of fibrosis and other tissue damage in patients diagnosed with hemochromatosis, as well as the occurrence of numerous endocrine disorders, e.g. hypogonadism (James 1964; lyer et al. 1981).

Hypogonadism is considered one of the most common endocrine abnormalities in men with hemochromatosis (Simon et al. 1972; Bezwoda et al. 1977; Kelly et al. 1984; Siemons and Mahler 1987), whereas in post-menopausal women the disease is rarely associated with either premature ovarian failure or subnormal levels of pituitary gonadotropins (Bezwoda et al. 1977; Altman et al. 1980; Kelly et al. 1984).

It is believed that excessive iron deposition may result in gonadal insufficiency by damaging Leydig cells that produce testosterone or gonadotropin-producing pituitary gonadotrophs that secrete follicle-stimulating hormone and luteinizing hormone. Hypogonadism most often results from abnormal functioning of the central system (pituitary gland or hypothalamus), but the gonadal defect with the pituitary function preserved was described (Kelly et al. 1984).

The occurrence of this disease was connected with disorders of the circulatory system (James 1964). A study by James (1964) showed that in five patients with hemochromatosis iron deposition was associated with tissue damage in the atrioventricular node but not in the sinus node (at the same time as the sinus node). However, it is difficult to say which of these disorders are primary and which are secondary. Previous studies show that some of them may be secondary and may result from damage to the liver or other tissues due to excessive iron deposition, or may be a direct result of its accumulation (Diamond et al. 1989).

\section{HEMOCHROMATOSIS IN THE RED DEER}

In 2011, research was carried out on 6 specimens of the red deer (Cervus elaphus) affected by hemochromatosis. The research was aimed, among others, at understanding the genetic basis of this disease. The red deer HFE gene is characterized by $96 \%$ nucleotide sequence homology and $96 \%$ amino acid sequence homology in comparison to the Bos taurus HFE gene and $82 \%$ homology to the nucleotide sequence in comparison to the black 
rhinoceros, $77 \%$ compared to the human sequence and $69 \%$ compared to the mouse sequence. No mutations present in humans and related to the occurrence of hemochromatosis were found in the studied subjects. In addition, the p.S88T polymorphism found in the black rhinoceros, which allows individuals to adapt to low levels of iron in their diet, has not been identified. However, two differences - A/T72V and V214A - were identified in the sequence of the HFE gene in the deer compared to the HFE gene sequence in human and cattle. The first one is located in the domain of the HFE protein; therefore it may have an effect on the interaction with the transferrin receptor. The analysis did not show differences in the threedimensional structure or chemical properties of the HFE gene in the red deer compared to the human and cattle gene (Olias et al. 2011).

Hemochromatosis was also found in the Svalbard reindeer (Rangifer tarandus platyrhynchus), yet, according to the studies, in this species the disease is of environmental nature (Borch-lohnsen and Thorstense 2009; Klopfleisch and Olias 2012).

\section{HEMOCHROMATOSIS IN OTHER SPECIES OF MAMMALS}

Mutations in the HFE gene associated with the occurrence of hemochromatosis have also been observed in other animal species, such as the black rhinoceros (Diceros bicornis).In this species the p.S88T mutation was selected as a candidate based on sequencing. However, further studies have shown that this polymorphism is an adaptation to low levels of iron in the diet (Beutler et al. 2001).

Previous studies have only allowed identification of genes that may be associated with the occurrence of hemochromatosis in mice. These include: the HAMP gene encoding hepcidin antimicrobial peptide (Nicolas et al. 2001; Lesbordes-Brion et al. 2006), the SMAD4 gene encoding SMAD family member 4 (Wang et al. 2005), the BMP6 gene encoding bone morphogenetic protein 6 (Meynard et al. 2009), TMPRSS6 gene encoding transmembrane serine protease 6 (Folgueras et al. 2008), HFE gene (Zhou et al. 1998; Bahram et al. 1999), B2M gene encoding beta-2 -microglobulin (de Sousa et al. 1994), the HJV gene (Niederkofler et al. 2005), the FPN1 gene encoding ferroportin-1 (Zohn et al. 2007) and the TfR2 gene coding for transferrin receptor 2 (Fleming et al. 2002). Studies conducted in other animal species only allowed indicating the potential mechanism of hemochromatosis; in some cases mutations found in humans were excluded from the group related to the conditioning of this disease in these species. In Salers cattle (House et al. 1994; O'Toole et al. 2001) and rhinoceros (Kock et al. 1994; Beutler et al. 2001; Olias et al. 2012), the occurrence of hemochromatosis has been associated with the presence of the HFE gene mutation. In Mynah bird, however, the occurrence of hemochromatosis has been associated with abnormal levels of DMT-1 and FPN-1 gene expression (Mete et al. 2005).

Hemochromatosis is also know to occur in the domestic dog but its genetic background has not been yet determined (Sprague et al. 2003).

\section{CONCLUSIONS}

Hemochormatosis is an excessive deposition of iron that can lead to numerous tissue and organ damage. The liver is primarily at risk; however, previous studies indicate that primary or secondary damage may affect all organs. The disease is best known in humans, but its occurrence has also been observed in many species of animals, including those living in 
natural environment and far from human. The occurrence of this disease in wild animals such as red deer or Svalbard reindeer may lead to weakening of the population. Additionally, in the case of hereditary form of hemochromatosis inherited as autosomal recessive, it can be transferred between populations. In order to understand the genetic background of hemochromatosis in the red deer, further research should be carried out, which eventually will allow to broaden the knowledge on iron metabolism in this species. Moreover, the results of these studies may reveal the previously unknown background of many diseases or developmental abnormalities in individuals of this species.

\section{REFERENCES}

Altman J.J., Zygelman M., Roger M., Fiet J., Passa P. 1980. Tha GnRH test in idiopathic hemochromatosis. J. Endocrinal. Invest. 3, 223-227.

Bacon B.R., Britton R.S. 1990. The pathology of hepatic iron overload: a free radical-mediated process? Hepatology 11, 127-137.

Bahram S., Gilfillan S., Kuhn L.C., Moret R., Schulze J.B., Lebeau A., Schümann K. 1999. Experimental hemochromatosis due to MHC class I HFE deficiency: immune status and iron metabolism. Proc. Natl. Acad. Sci. USA 96, 13312-13317.

Bahram S., Gilfillan S., Kühn LC., Moret R., Schulze J.B., Lebeau A., Schümann K. 1999. Experimental hemochromatosis deu to MHC class I HFE deficiency immune status and iron metabolism. Proc. Natl. Acad. Sci. USA 96(23), 13312-13317.

Beutler E., West C., Speir J.A., Wilson I.A., Worley M. 2001. The hHFE gene of browsing and grazing rhinoceroses: a possible site of adaptation to a low-iron diet. Blood Cells Mol. Dis. 27(1), 342-350.

Bezwoda W.R., Bothwell T.H., Walt L.A. van der, Kronheim S., Pimstone B.L. 1977. An investigation into gonadal dysfunction in patients with idiopathic haemochromatosis. Clin. Endocrinol. (Oxf) 6, 377-385.

Borch-Iohnsen B., Thorstensen K. 2009. Iron distribution in the liver and duodenum during seasonal iron overload in Svalbard reindeer. J. Comp. Path. 141, 27-40.

Chmielnicka J. 2012. Toksyczność metali i półmetali (metaloidów), w: Toksykologia współczesna. Red. W. Seńczuk. Warszawa, PZWL, 442-446. [in Polish]

De Sousa M., Reimao R., Lacerda R., Hugo P., Kaufmann S.H., Porto G. 1994. Iron overload in B2-microglobulin-deficient mice. Immunol. Lett. 39, 105-111.

Derc K., Grzymisławski M., Skarupa-Szabłowska G. 2001. Hemochromatoza pierwotna [Primary hemochromatosis]. Gastroenterol. Pol. 8, 181-188. [in Polish]

Diamond T., Stiel D., Posen S. 1989. Osteoporosis in hemochromatosis: iron excess, gonadal deficiency, or other factors? Ann. Intern. Med. 110(6), 430-436.

Drakewmith H., Schimanski L.M., Ormerod E., Merryweather-Clarke A.T., Viprakasit V., Edwards J.P., Sweetland E., Bastin J.M., Cowley D., Chinthammitr Y., Robson K.J., Townsend A.R. 2005. Resistance to hepcidin is conferred by hemochromatosis-associated mutations of ferroportin. Blood 106, 1092-1097.

Edwards C.Q., Griffen L.M., Goldgar D., Drummond C., Skolnick M.H., Kushner J.P. 1988. Prevalence of hemochromatosis among 11,065 presumably healthy blood donors. N. Engl. J. Med. 318, $1355-1362$.

Feder J.N., Gnirke A., Thomas W., Tsuchihashi Z., Ruddy D.A., Basava A., Dormishian F., Domingo Jr. R., Ellis M.C., Fullan A., Hinton L.M. Jones N.L., Kimmel B.E., Kronmal G.S., Lauer P., Lee V.K., Loeb D.B., Mapa F.A., McClelland E., Meyer N.C., Minitier G.A., Noeller N., Moore T., Morikang E., Prass C.E., Quintana L., Starnes S.M., Schatzman R.C., Brunke K.J., Drayna D.T., Risch N.J., Bacon B.R., Wolff R.K. 1996. A novel MHC class I-like gene is mutated in patients with hereditary haemochromatosis. Nat. Genet. 13(4), 399-408. 
Fleming R.E., Ahmann J.R., Migas M.C., Waheed A., Koeffler H.P., Kawabata H., Britton R.S., Bacon B.R., Sly W.S. 2002. Targeted mutagenesis of the murine transferrin receptor-2 gene produces hemochromatosis. Proc. Natl. Acad. Sci. USA 99, 10654-10658.

Folgueras A.R., Lara FM. de, Pendas A.M., Garabaya C., Rodriguez F., Astudillo A., Bernal T., Cabanillas R., López-Otín C., Velasco G. 2008. Membrane-bound serine protease matriptase-2 (Tmprss6) is an essential regulator of iron homeostasis. Blood 112, 2539-2545.

Ganz T. 2003. Hepcidin, a key regulator of iron metabolism and mediator of anemia of inflammation. Blood 102, 783-788.

House J.K., Smith B.P., Maas J., Lane V.M., Anderson B.C., Graham T.W., Pino M.V. 1994. Hemochromatosis in Salers Cattle. J. Vet. Intern. Med. 8(2), 105-111.

Hübscher S.G. 2003. Iron overload, inflammation and fibrosis in genetic haemochromatosis. J. Hepatol. 38, 521-525.

lyer R., Duckworth W.C., Solomon S.S. 1981. Hypogonadism in idiopathic hemochromatosis. Arch. Intern. Med. 141, 517-518.

James T.N. 1964. Pathology of the cardiac conduction system in hemochromatosis. N. Eng. J. Med. 271(2), 92-94.

Kelly T.M., Edwards C.Q., Meikle A.W., Kushner J.P. 1984. Hypogonadism in hemochromatosis: reversal with iron depletion. Ann. Intern. Med. 101(5), 629-632.

Klopfleisch R., Olias P. 2012. The pathology of comparative animal models of human haemochromatosis. J. Comp. Path. 147, 460-478.

Knutson M.D., Oukka M., Koss L.M., Aydemir F., Wessling-Resnick M. 2005. Iron release from macrophages after erythrophagocytosis is up-regulated by ferroportin 1 overexpression and downregulated by hepcidin. Proc. Natl. Acad. Sci. USA 102, 1324-1328.

Ko C., Siddaiah N., Berger J., Gish R., Brandhagen D., Sterling R.K., Cotler S.J., Fontana RJ., McCashland T.M., Han S.H.B., Gordon F.D., Schilsky M.L., Kowdley K.V. 2007. Prevalence of hepatic iron overload and associated with hepatocellular cancer in end-stage liver disease: results from the National Hemochromatosis Transplant Registry. Liver. Int. 27, 1394-1401.

Kock N.D., Foggin C., Kock M.D., Kock R. 1994. Hemosiderosis in the black rhinoceros (Diceros bicornis): a comparison of free ranging and recently captured with translocated and captive animals. J. Zoo Wildl. Med. 2, 230-234.

Korzeniowska K., Cieślewicz A., Jabłecka A. 2012. Zaburzenia gospodarki żelaza. Cz. 1. Hemochromatoza [Disorders of iron balance. Part 1. Hemochromatosis]. Farmacja Współ. 5, 83-87. [in Polish]

Kulej D., Mielcarek M., Kałwak K. 2012. Ocena skuteczności terapii chelatującej deferazyroksem u pacjentów pediatrycznych z hemosyderozą wtórną po allogenicznej transplantacji komórek macierzystych [Evaluation of the effectiveness of deferasirox chelation therapy in pediatric patients with secondary hemosiderosis after allogeneic stem cell transplantation]. Onkol. Pol. 15, 24-29. [in Polish]

Lanzara C., Roetto A., Daraio F., Rivard S., Ficarella R., Simard H., Cox T.M., Cazzola M., Piperno A., Gimenez-Roqueplo A.P., Grammatico P., Volinia S., Gasperini P., Camaschella C. 2004. Spectrum of hemojuvenil gene mutations in 1q-linked juvenile hemochromatosis. Blood 103, 4317-4321.

Lesbordes-Brion J.C., Viatte L., Bennoun M, Lou D.Q., Ramey G. Houbron C., Hamard G., Kahn A., Vaulont S. 2006. Targeted disruption of the hepcidin 1 gene results in severe hemochromatosis. Blood 108, 1402-1405.

Levy J.E., Montross L.K., Cohen D.E., Fleming M.D., Andrews N.C. 1999. The C282Y mutation causing hereditary hemochromatosis does not produce a null allele. Blood 94(1), 9-11.

Lipiński P., Starzyński R.R., Gajowiak A., Staroń R., Styś A. 2014. Metabolizm żelaza - stan wiedzy 2014 [Metabolism of iron - state of knowledge 2014]. KOSMOS, Probl. Nauk Biolog. 63(3), 299-308. [in Polish] 
Merryweather-Clarke A.T., Pointon J.J., Jouanolle A.M., Rochette A.M., Robson K.J. 2000. Geography of HFE C282Y and H63D mutations. Genet. Test. 4(2), 183-198.

Merryweather-Clarke A.T., Pointon J.J., Shearman J.D., Robson K.J. 1997. Global prevalence of putative haemochromatosis mutations. J. Med. Genet. 34(4), 275-278.

Mete A., Jalving R., Oost B.A. van, Dijk J.E. van, Marx J.J.M. 2005. Intestinal over-expression of iron transporters induces iron overload in birds in captivity. Blood Cells Mol. Dis. 34, 151-156.

Meynard D., Kautz L., Darnaud V., Canonne-Hergaux F., Coppin H., Roth M.P. 2009. Lack of the bone morphogenetic protein BMP6 induces massive iron overload. Nat. Genet. 41, 478-481.

NCBI, HFE homeostatic iron regulator [Homo sapiens (human)], https://www.ncbi.nlm.nih.gov/ Igene?Db=gene\&Cmd=ShowDetailView\&TermToSearch=3077, access: 20.05.2018.

Nemeth E., Roetto A., Garozzo G., Ganz T., Camaschella C. 2005. Hepcidin is decreased in TFR2 hemochromatosis. Blood 104, 1803-1806.

Nicolas G., Bennoun M., Devaux I., Beaumont C., Grandchamp B., Kahn A., Vaulont S. 2001. Lack of hepcidin gene expression and severe tissue iron overload in upstream stimulatory factor 2 (USF2) knockout mice. Proc. Natl. Acad. Sci. USA 98, 8780-8785.

Niederkofler V., Salie R., Arber S. 2005. Hemojuvenil is essential for dietary iron sensing, and its mutation leads to severe iron overload. J. Clin. Invest. 115, 2180-2186.

NIH. 2014. Hemochromatosis, https://www.niddk.nih.gov/health-information/iver-disease/hemochromatosis, access: 20.05.2018.

O'Toole D., Kelly E.J., McAllister M.M., Layton A.W., Norrdin R.W., Russell W.C., Saeb-Parsy K., Walker A.P. 2001. Hepatic failure and hemochromatosis of Salers and Salers-cross cattle. Vet. Pathol. 38, 372-389.

Olias P., Mundhenk L., Bothe M., Ochs A., Gruber A.D. Klopfleisch R. 2012. Iron overload syndrome in the black rhinoceros (Diceros bicornis): microscopical lesions and comparison with other rhinoceros species. J. Comp. Pathol. 147(4), 542-549.

Olias P., Weiss A.Th.A., Gruber AD., Klopfleisch R. 2011. Iron storage disease in Red Deer (Cervus elaphus elaphus) is not associated with mutations in the HFE gene. J. Comp. Pathol. 45, 207-213.

Phatak P.D., Sharm R.L., Raubertas R.F., Dunnigan K., O’Leary M.T., Braggins C., Cappuccio J.D. 1998. Prevalence of hereditary hemochromatosis in 10631 primary care patients. Ann. Intern. Med. 129, 954-961.

Pietrangelo A., Gualdi R., Casalgrandi G., Montosi G., Vanura E. 1995. Molecular and cellular aspects of iron-induced hepatic cirrhosis in rodents. J. Clin. Invest. 95, 1824-1831.

Raszeja-Wyszomirska J., Ławniczak M., Milkiewicz P. 2008. Nowe aspekty patogenetyczne wrodzonej hemochromatozy [New pathogenetic aspects of hereditary hemochromatosis]. Pol. Merk. Lek. 24(139), 54. [in Polish]

Reeves H.L., Friedman S.L. 2002. Activation of the hepatic stellate cells - a key issue in liver fibrosis. Front. Biosci. 7, d808-826.

Robson K.J. 2004. Hepcidin and its role in iron absorption. Gut 53, 617-619.

Roetto A., Papanikolau G., Politou M., Alberti F., Girelli D., Christiakis J., Loukopoulos D., Camaschella C. 2003. Mutant antimicriobial peptide hepcidin is associated with severe juvenile hemochromatosis. Nat. Genet. 33, 21-22.

Siemons L.J., Mahler C.H. 1987. Hypogonadotropic hypogonadism in hemochromatosis: recovery of reproductive function after iron depletion. J. Clin. Endocrinol. Metab. 65(3), 585-587.

Sikorska K. 2014. Nadmierne gromadzenie żelaza w organizmie - realne zagrożenie dla zdrowia człowieka? [Excessive iron accumulation in the body - a real threat to human health?]. KOSMOS, Probl. Nauk Biolog. 63(3), 315-323. [in Polish]

Sikorska K., Bielawski K.P., Romanowski T., Stalke P. 2006. Hemochromatoza dziedziczna najczęstsza choroba genetyczna człowieka [Hereditary hemochromatosis: the most frequent inherited human disease.] Post. Hig. Med. Dośw. 60, 667-676. [in Polish] 
Simon M., Franchimont P., Murie N., Ferrand B., Cauwenberge H. van, Bourel M. 1972. Study of somatotropic and gonadotropic pituitary function in idiopatic haemochromatosis (31 cases). Eur. J. clin. Invest. 2, 384-389.

Simon P., Bourel M., Genetet B., Fauchet R. 1977. Idiopathic hemochromatosis. Demonstration of recessive transmission and early detection by family HLA typing. N. Eng. J. Med. 297, 1017-1021.

Sprague W.S., Hackett T.B., Johnson J.S., Swardson-Olver C.J. 2003. Hemochormatosis secondary to repeated blood transfusion in a dog. Vet. Pathol. 40, 334-337.

The Human Protein Atlas. 2018, https://www.proteinatlas.org/ENSG00000010704-HFE/, access: 20.05.2018.

Videla L.A., Fernandez V., Tapia G., Varela P. 2003. Oxidative stress-mediated hepatotoxicity of iron anc copper: role of Kupffer cells. Biometals 16, 103-111.

Wang R.H., Li C., Xu X., Zheng Y., Xiao C., Zerfas P., Cooperman S., Eckhaus M., Rouault T., Mishra L., Deng C.X. 2005. A role of SMAD4 in iron metabolism through the positive regulation of hepicidin expression. Cell Metab. 2(6), 399-409.

Zabielski R. 2005 Trawienie i wchłanianie, w: Fizjologia zwierząt. Warszawa, PWRiL, 505. [in Polish]

Zhou X.Y., Tomatsu S., Fleming R.E., Parkkila S., Waheed A., Jiang J., Fei Y., Brunt E.M., Ruddy D.A., Prass C.E., Schatzman R.C., O'Neill R., Britton R.S., Bacon B.R., Sly W.S. 1998. HFE gene knockout produces mouse model of hereditary hemochromatosis. Proc. Natl. Acad. Sci. USA 95(5), 2491-2497.

Zohn I.E., De Domenico I., Pollock A., Ward D.M., Goodman J.F. Liang X., Sanchez A.J., Niswander L., Kaplan J. 2007. The flatiron mutation in mouse ferroportin acts as a dominant negative to cause ferroportin disease. Blood 109, 4174-4180.

\title{
PODŁOŻE GENETYCZNE I SKUTKI NADMIERNEGO GROMADZENIA ŻELAZA U RÓŻNYCH GATUNKÓW SSAKÓW
}

\begin{abstract}
Streszczenie. Hemochromatoza jest chorobą metaboliczną związaną z nadmiernym odkładaniem żelaza w organizmie. Obecnie u człowieka wyróżniamy 5 typów tej choroby, różniących się podłożem genetycznym oraz sposobem dziedziczenia, a także częstością występowania. Ze względu na możliwość wystąpienia skutków śmiertelnych nadmierne odkładanie żelaza jest zaburzeniem poważniejszym niż jego niedobór. W chorobie tej żelazo gromadzone jest $\mathrm{w}$ organizmie $\mathrm{w}$ formie hemosyderyny, czyli białkowego kompleksu magazynującego żelazo w komórkach. Występowanie tej choroby zaobserwowano nie tylko u człowieka, ale także u innych gatunków zwierząt, takich jak jeleń szlachetny, nosorożec czarny, mysz domowa czy bydło domowe. Niniejszy artykuł ma na celu przedstawienie mechanizmów warunkowania hemochromatozy u człowieka, prawidłowego metabolizmu żelaza, występowania tej choroby u jelenia szlachetnego oraz jej wpływu na biologię i populację tego gatunku.
\end{abstract}

Słowa kluczowe: hemochromatoza, jeleń szlachetny, metabolizm żelaza. 